Mateusz Ktucjasz*

https://doi.org/10.18778/8220-375-2.08

\title{
Relacje gospodarcze pomiędzy Chińską Republiką Ludową i państwami Afryki od 2000 roku Inwestycje infrastrukturalne $i$ związane z nimi kontrowersje
}

\begin{abstract}
Economic relations between the People's Republic of China and African countries since 2000. Infrastructure investments and related controversies
\end{abstract}

From the beginning of the twenty-first century, we can see the intensification of political and economic relations between the People's Republic of China and the African continent. One of the most important factors that shape these relationships is the economic aspect. The aim of the study was to check how these relations developed and what character the current economic relations between the People's Republic of China and African countries have. Research questions focus on: people who contributed to the establishment of relations between the PRC and African countries; the position of the African continent in the Chinese strategy, with particular emphasis on infrastructure investments carried out under the One Belt One Road (OBOR) plan; processes that contribute to the interest of major players internationally in African countries; implications of the Chinese-African relationship for African countries. The historical, statistical and content analysis method was used to examine this topic. Quantitative and qualitative data were used during the study. The sources used here were press articles, reports, books and statistical data. Intensification of political relations between the People's Republic of China and the African continent has a direct impact on trade and economic relations. The announcement of plans related to the construction of transport infrastructure played an important role in this. Investments and the presence of Chinese enterprises in Africa have a positive effect on building the social capital of African countries. In ChineseAfrican relations, the issue of debt diplomacy is a frequently raised issue, but doubts about the profitability of certain investment projects are a much more important issue in these relations.

Keywords: economic relations between the People's Republic of China and African countries, foreign investments, OBR, infrastructure

Słowa kluczowe: chińsko-afrykańskie relacje gospodarcze, inwestycje zagraniczne, OBOR, infrastruktura

"Absolwent logistyki na Uniwersytecie Łódzkim, student studiów II stopnia, kierunek stosunki międzynarodowe, specjalność orientalna na Wydziale Studiów Międzynarodowych i Politologicznych UŁ; e-mail: mateusz.klucjasz@unilodz.eu. 


\section{Wstęp}

Waszyngtońscy politycy jako główny powód rozpoczęcia wojny gospodarczej z Chinami wskazują deficyt Stanów Zjednoczonych w handlu z Chińską Republiką Ludową. Jest to ważny czynnik kształtujący relacje ekonomiczne tych państw. Z tego powodu należy zwrócić uwagę na szerszy kontekst powstałej sytuacji. Chiny od 2013 roku oficjalnie zaczęły kontestować pozycję USA jako głównego aktora w gospodarce światowej. Aby uzyskać przewagę nad Stanami Zjednoczonymi, państwo to musi zdobyć większą kontrolę nad głównymi szlakami transportowymi. $Z$ tego powodu kluczową rolę w strategii władz chińskich odgrywa kontynent afrykański. Region ten, nieposiadający dobrze rozwiniętej infrastruktury transportowej, stał się jednym z beneficjentów ogłoszonych stosunkowo niedawno programów inwestycyjnych realizowanych przy udziale oraz wsparciu chińskich podmiotów gospodarczych. Afryka posiada duży potencjał, aby w bliskiej przyszłości stać się jednym z ważniejszych rynków światowego handlu, dlatego w interesie Chin leży pomoc krajom afrykańskim w ich rozwoju. Projekty te są realizowane za pomocą kredytów, które niosą za sobą ryzyko związane z przeszacowaniem inwestycji, co może powodować problemy z płynnością finansową państw afrykańskich.

Niniejsza publikacja ma na celu przedstawienie relacji gospodarczych pomiędzy Chińską Republiką Ludową i kontynentem afrykańskim w XXI wieku. Zwraca się w niej również uwagę na istotne znaczenie Afryki w chińskiej polityce międzynarodowej. W pierwszej części skupiono się na wydarzeniach konstytuujących owe stosunki oraz skutki ekonomiczne tych zdarzeń. Druga część pracy przedstawia główne projekty inwestycyjne realizowane przez podmioty chińskie oraz źródło ich finansowania. W trzeciej części artykułu zwrócono uwagę na kontrowersje dotyczące realizacji projektów transportowych, oskarżenia kierowane przez zachodnie państwa w kierunku Chińskiej Republiki Ludowej oraz wpływ inwestycji na lokalne społeczności i ich sytuację ekonomiczną.

\section{Kształtowanie się relacji politycznych i gospodarczych pomiędzy Chińską Republiką Ludową i Afryką}

W pierwszych latach po II wojnie światowej Chiny w kontaktach z Afryką kierowały się przede wszystkim względami ideologicznymi. Otwarcie wspierały one dążenia narodów afrykańskich do uzyskania niepodległości w okresie dekolonizacji ${ }^{1}$. Pomoc ta nie miała jedynie charakteru deklaratywnego, gdyż w latach 50. i 60. XX wieku część krajów afrykańskich otrzymała również wsparcie materialne od narodu chińskiego ${ }^{2}$. Jednym z ważniejszych wydarzeń

${ }^{1}$ W. Nowak, China-Africa and India-Africa trade in the years 2000-2014, „Procedia Economics and Finance" 2016, Vol. XXXIX, s. 140-146.

${ }^{2}$ Idem, China's Development Aid Strategies, „Chinese Business Review” 2015, Vol. XIV, No. 4, s. 201-209. 
kształtujących relacje pomiędzy Chinami i Afryką były wizyty premiera ChRL Zhou Enlaia w dziesięciu afrykańskich państwach na przełomie lat 1963-1964. Podczas tych spotkań chiński przedstawiciel zapewniał kraje afrykańskie „o niesłabnącym wsparciu w ich walce z siłami imperialistycznymi” ${ }^{3}$. Z punktu widzenia ekonomicznego rozwoju kontynentu istotniejszą kwestią była jednak deklaracja dotycząca finansowania projektów inwestycyjnych, które miały stymulować wzrost gospodarczy nowo powstałych państw ${ }^{4}$. Najbardziej znanym przedsięwzięciem z tamtego okresu było chińskie wsparcie budowy linii kolejowej, która połączyła Tanzanię z Zambią ${ }^{5}$.

W kształtowaniu się relacji chińsko-afrykańskich kluczową rolę odegrał przywódca ChRL Mao Zedong. Pierwsza połowa lat 70. stała pod znakiem zmiany układu sił na arenie międzynarodowej. Wizyta prezydenta Stanów Zjednoczonych Richarda Nixona w Chińskiej Republice Ludowej ${ }^{6}$ oraz późniejsze kroki zmierzające ku normalizacji stosunków pomiędzy oboma państwami umożliwiły Chinom sformułowanie nowej koncepcji dotyczącej relacji z partnerami zewnętrznymi. Mao Zedong na początku 1974 roku ogłosił teorię trzech światów, która dzieliła państwa na trzy kategorie. Stany Zjednoczone oraz Związek Socjalistycznych Republik Radzieckich zostały uznane za członków „pierwszego świata”, natomiast Chiny wraz z krajami rozwijającymi się należały do państw trzeciej kategorii. Taki podział dał możliwość Chińskiej Republice Ludowej na większą niezależność w kontaktach z krajami afrykańskimi. Mogła się ona również pozycjonować jako lider państw, które dążą do uzyskania suwerenności i stabilności ekonomicznej

Choć z doktryną tą wiązano duże nadzieje, to polityka zagraniczna Państwa Środka w drugiej połowie lat 70. musiała zejść na drugi plan. Było to związane $\mathrm{z}$ rozpoczęciem rewolucji kulturalnej oraz wielkich reform gospodarczych, które w znaczący sposób wpłynęły na relacje Chin z państwami afrykańskimi ${ }^{8}$. W okresie tym można zauważyć wyraźny spadek wymiany handlowej pomiędzy Chińską Republiką Ludową i Afryką. Głównym powodem tego było skupienie się Chin na rozwiązywaniu problemów wewnętrznych, przez co relacje te zostały zaniedbane. Doktryna trzech światów znalazła jednak zastosowanie w późniejszych latach i była wielokrotnie przywoływana przez przywódców ChRL podczas kontaktów z państwami Afryki.

\footnotetext{
${ }^{3}$ Premier Zhou Enlai's Three Tours of Asian and African Countries, https://www.fmprc.gov.cn/ mfa_eng/ziliao_665539/3602_665543/3604_665547/t18001.shtml (dostęp: 20.12.2019).

${ }^{4}$ Ibidem.

${ }^{5}$ J. Monson, Africa's Freedom Railway: How a Chinese Development Project Changed Lives and Livelihoods in Tanzania, Bloomington 2009, s. 22.

${ }^{6} \mathrm{H}$. Kissinger, O Chinach, Wołowiec 2014, s. 264.

${ }^{7}$ Ibidem, s. 308-309.

${ }^{8}$ E. Obuah, Trade between China and Africa: Trends, Changes, and Challenges, „International Journal of China Marketing” 2012, Vol. II, No. 2, s. 74-88.
} 
Prawdziwy rozkwit w relacjach gospodarczych pomiędzy Chinami i kontynentem afrykańskim rozpoczął się w 1994 roku wraz z wprowadzeniem przez chiński rząd Wielkiego Planu Współpracy Ekonomicznej i Handlowej. W tym właśnie roku utworzono EXIM Bank of China, którego zadaniem miało być udzielanie pożyczek krajom rozwijającym się na projekty inwestycyjne związane z rozwojem handlu światowego. Od powstania Chińsko-Afrykańskiego Forum Współpracy (Forum on China-Africa Cooperation, FOCAC) w 2000 roku można zauważyć wiele decyzji przedstawicieli chińskich, które prowadzily do ułatwień w handlu oraz współpracy gospodarczej pomiędzy tymi podmiotami. Jednym z pierwszych postanowień zawartych w ramach Forum było umorzenie przez ChRL długu o wartości 10 miliardów dolarów najbiedniejszym państwom afrykańskim 9 . Gest ten świadczył o tym, że chińska współpraca gospodarcza z krajami Afryki ma mieć charakter długotrwały i strategiczny.

Piąta generacja przywódców Chińskiej Republiki Ludowej, która kieruje państwem od marca 2013 roku $^{10}$, również zdążyła już pokazać, jak ważne są dla niej stosunki polityczne i gospodarcze z Afryką. Obecny prezydent Xi Jinping w ramach swojej pierwszej wizyty zagranicznej udał się na kontynent afrykań$\mathrm{ski}^{11}$. Podczas przemówienia w Dar es Salaam przywódca ChRL, nawiązując do wspólnej historii, zaznaczył, że Chiny w dalszym ciągu będą wspierać finansowo Afrykę, szanując przy tym jej niezależność w podejmowaniu decyzji o wyborze drogi rozwoju. Podkreślił również, że interesy narodu chińskiego są zbieżne z interesami krajów afrykańskich. To pierwsze stwierdzenie budzi najwięcej kontrowersji w krajach zachodnich, które często oskarżają Chiny o wspieranie przywódców autorytarnych. Strategia Chińskiej Republiki Ludowej dotycząca Afryki nie opiera się jedynie na pogłębianiu współpracy gospodarczej. Podczas tego samego wystąpienia wspomniano też o zacieśnianiu stosunków międzyludzkich poprzez wspólne programy edukacyjne, które mają pomóc w rozwoju kapitału społecznego państw afrykańskich ${ }^{12}$.

Prezydent Xi Jinping już w pierwszym roku swojej kadencji sformułował plany dotyczące pozycji Chińskiej Republiki Ludowej w światowym systemie gospodarczym. Podczas wizyty w Astanie 7 września 2013 roku przedstawił zarys inicjatywy „Jeden pas, jedna droga” (One Belt, One Road, OBOR), która przez wielu specjalistów nazywana jest nowym „planem Marshalla”'13. Projekt zakłada budowę lub modernizację infrastruktury transportowej, tworząc tym

\footnotetext{
${ }^{9}$ W. Nowak, China-Africa and India-Africa...

${ }^{10}$ B. Góralczyk, Chiny piątej generacji, https://www.obserwatorfinansowy.pl/tematyka/makroekonomia/chinypiatejgeneracji/ (dostęp: 20.12.2019).

${ }^{11}$ More than minerals, „The Economist”, 23.03.2013, s. 35-36.

${ }^{12} \mathrm{X}$. Jinping, Innowacyjne Chiny, Warszawa 2015, s. 314.

${ }^{13} \mathrm{R}$. ZiroMwatela, Z. Changfeng, Africa in China's „One Belt, One Road” Initiative: A Critical Analysis, „IOSR Journal of Humanities and Social Science” 2016, Vol. XXI, No. 12, s. 10-21.
} 
samym nowe szlaki tranzytowe łączące Chiny z regionem euroazjatyckim oraz Afryką. Koncepcja owa składa się z dwóch elementów: Lądowego Jedwabnego Szlaku i Morskiego Jedwabnego Szlaku ${ }^{14}$. Plan ma znaczenie strategiczne dla rozwoju Chińskiej Republiki Ludowej oraz kontynentu afrykańskiego. Chiny dzięki niemu zyskają większą kontrolę nad międzynarodowym handlem, co znacząco poprawi ich pozycję w światowym systemie ekonomicznym. Dla Afryki projekt ten jest szansą na rozwój swojej infrastruktury transportu morskiego oraz kolejowego, która będzie stymulować wzrost gospodarczy regionu poprzez wymianę handlową ${ }^{15}$.

Wykres 1. Handel zagraniczny pomiędzy Chinami i Afryką w latach 2000-2018

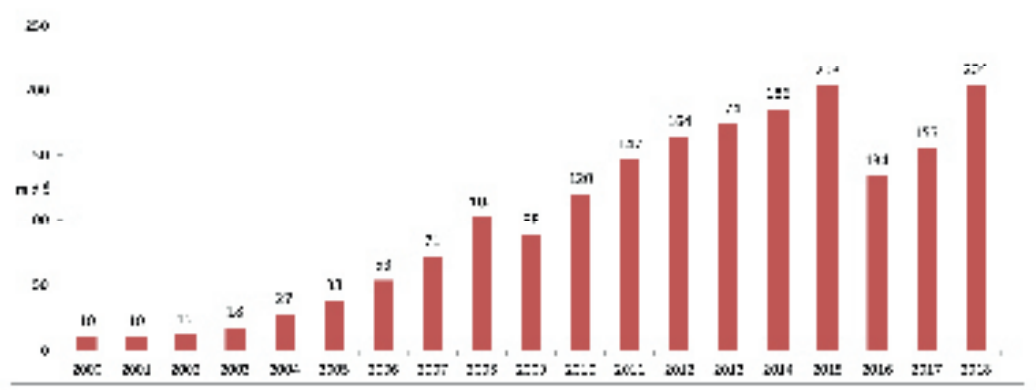

Źródło: opracowanie własne na podstawie danych Organizacji Narodów Zjednoczonych, http://www.sais-cari.org/data-china-africa-trade (dostęp: 19.12.2019).

Kroki podjęte przez chińskie władze w celu pogłębienia relacji gospodarczych z kontynentem afrykańskim mają odzwierciedlenie w danych dotyczących handlu zagranicznego (wykres 1). Wymiana towarowa pomiędzy Chinami i Afryką od początku XXI wieku wzrosła niemal dwudziestokrotnie. Oznacza to, że Chińska Republika Ludowa stała się największym partnerem handlowym kontynentu afrykańskiego ${ }^{16}$. Trend wzrostowy w wyżej wymienionym okresie był przerywany dwukrotnie. W 2008 roku upadek Lehmann Brothers spowodował kryzys gospodarczy, który wyrządził szkody wszystkim aktorom operującym na rynku światowym ${ }^{17}$, natomiast rok 2015 stał w Chinach pod znakiem

${ }^{14} \mathrm{P}$. Nantulya, Implications for Africa from China's One Belt One Road Strategy, https://africacenter.org/spotlight/implicationsforafricachinaonebeltoneroadstrategy/ (dostęp: 21.12.2019).

${ }^{15}$ Ibidem.

${ }^{16}$ Opracowanie własne na podstawie http://www.sais-cari.org/datachinaafricatrade (dostęp: 21.12.2019).

${ }^{17}$ M. Gawęda, Lehman Brothers - symboliczny upadek, który rozpocząt kryzys finansowy, https://www.forbes.pl/gospodarka/upadek-lehman-brothers-rozpoczal-kryzys-finansowyw-2008-roku/7j1fgjh (dostęp: 21.12.2019). 
dużych spadków na giełdzie papierów wartościowych, które stały się jednym z powodów zmniejszenia wartości eksportu oraz importu ${ }^{18}$.

Produktami najchętniej kupowanymi przez Chińską Republikę Ludową od krajów afrykańskich są surowce naturalne i paliwa, dzięki którym Chiny mogą nadal utrzymywać wysokie tempo wzrostu ${ }^{19}$. W ostatnich latach, z powodu rosnącego zapotrzebowania $\mathrm{w}$ chińskim społeczeństwie na produkty rolne, przewiduje się, że to właśnie ta kategoria dóbr w przyszłości może odgrywać większą rolę $\mathrm{w}$ handlu pomiędzy tymi dwoma regionami ${ }^{20}$. Państwa Afryki, które w ostatnich latach bardzo szybko rozwijają swoją infrastrukturę energetyczną oraz transportową, kupują od Chin maszyny i sprzęt budowlany. Warto tu jednak zaznaczyć, że dużą rolę w eksporcie chińskim do Afryki odgrywają również dobra konsumpcyjne ${ }^{21}$, co świadczy o bogaceniu się społeczeństw afrykańskich.

\section{Chińskie inwestycje na kontynencie afrykańskim}

Zwiększanie się zagranicznego kapitału w Afryce jest w dużej mierze spowodowane potencjałem ekonomicznym tego regionu. Według raportów organizacji międzynarodowych, Afryka subsaharyjska może w niedługim czasie wyprzedzić Chiny pod względem liczby ludności ${ }^{22}$. $\mathrm{Z}$ tego powodu zaobserwować można wzrost znaczenia tego kontynentu na arenie międzynarodowej. Główni aktorzy systemu światowego chętniej otwierają tam swoje ambasady $\mathrm{w}$ celu pogłębiania stosunków dyplomatycznych z krajami afrykańskimi. Wzrost populacji danego regionu stwarza możliwość osiągnięcia większych zysków ze sprzedaży dóbr lub usług. Dlatego właśnie coraz więcej inwestorów zaczyna lokować swoje środki w Afryce. Choć firmy brytyjskie i amerykańskie wciąż inwestują tam najwięcej, to jednak chińskie przedsiębiorstwa w szybkim tempie zaczynają doganiać zachodnią konkurencję $e^{23}$.

Większość projektów mających na celu modernizację infrastruktury na kontynencie afrykańskim nie mogłaby dojść do skutku bez pożyczek zaciąganych u zagranicznych partnerów. Kredyty udzielane przez zachodnich sojuszników są bardzo często obwarowane dodatkowymi warunkami związanymi z przestrzeganiem wartości demokratycznych przez pożyczkobiorców. Wiele państw

\footnotetext{
${ }^{18}$ China has a serious crisis on its hands, https://www.youtube.com/watch?v=Zpzhh0y1RUo (dostęp: 21.12.2019).

${ }^{19} \mathrm{~J}$. Holslag, China's New Mercantilism in Central Africa, „African and Asian Studies” 2006, Vol. V, No. 2, s. 133-169.

${ }^{20}$ One among many, „The Economist”, 17.01.2015, s. 32.

${ }^{21}$ https://wits.worldbank.org/CountryProfile/en/Country/CHN/Year/2017/TradeFlow/Export/Partner/SSF/Product/all-groups (dostęp: 21.12.2019).

${ }^{22}$ C. Cookson, Africa to propel world's population towards 10 bn by 2050, https://www.ft.com/ content/868e20d090ec11e9b7ea60e35ef678d2 (dostęp: 21.12.2019).

${ }^{23}$ The new scramble for Africa, „The Economist”, 9.03.2019, s. 9.
} 
Afryki ma jednak problemy z przestrzeganiem praw człowieka, dlatego też niechętnie decydują się na tego typu zobowiązania ${ }^{24}$. W takich sytuacjach z pomocą przychodzi Chińska Republika Ludowa, udzielająca wsparcia finansowego zgodnie z wypracowanym przez siebie modelem „konsensusu pekińskiego", który zakłada nieingerowanie w wewnętrzną politykę państw ${ }^{25}$.

W ostatnich latach można zaobserwować znaczący wzrost ilości pieniędzy, które pożyczane są przez chińskie instytucje krajom afrykańskim (wykres 2). Najwięcej środków z tego źródła otrzymuje Angola ${ }^{26}$, kraj bogaty w surowce naturalne, jednak cierpiący na brak odpowiedniej infrastruktury, dzięki której mógłby się odpowiednio rozwijać ${ }^{27}$. Na drugim miejscu znajduje się Etiopia, mogąca się pochwalić szybkim wzrostem gospodarczym, który w głównej mierze nie był oparty na wydobyciu surowców naturalnych ${ }^{28}$. Oznacza to, że chińska pomoc nie we wszystkich przypadkach jest kierowana do państw mogących zaoferować w zamian paliwa kopalne i metale szlachetne.

Wykres 2. Wartość pożyczek udzielonych przez podmioty chińskie krajom Afryki w latach 2000-2017

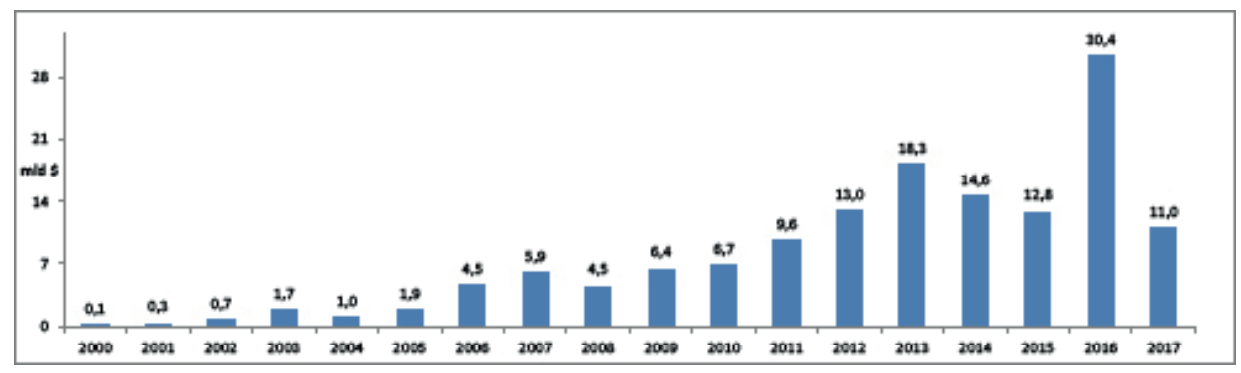

Źródło: opracowanie własne na podstawie danych China-Africa Research Initiative, http:// www.sais-cari.org/data (dostęp: 19.12.2019).

Środki te $\mathrm{w}$ dużej mierze były przekazywane na projekty związane $\mathrm{z}$ infrastrukturą transportową (30,57\% udziału w ogólnej kwocie pożyczek), energetyczną $(24,12 \%)$ i wydobywczą $(15,37 \%)$. Inwestycje w zaplecze transportowe są możliwe dzięki inicjatywie OBOR, w ramach której stworzono

\footnotetext{
${ }^{24}$ Beijing curbs its enthusiasm, „The Economist”, 29.06.2019, s. 33-34.

${ }^{25} \mathrm{E}$. Lammers, How will the Beijing Consensus benefit Africa? - China and Africa, https://www. thebrokeronline.eu/howwillthebeijingconsensusbenefitafrica/ (dostęp: 21.12.2019).

${ }^{26} \mathrm{http}$ ://www.sais-cari.org/data (dostęp: 22.12.2019).

${ }^{27}$ Rich in resources but poor and corrupt, https://www.dw.com/en/richinresourcesbutpoorandcorrupt/av40200307 (dostęp: 23.12.2019).

${ }^{28}$ Can Ethiopia's Resource Wealth Contribute to its Growth and Transformation?, https://www. worldbank.org/en/news/feature/2015/01/26/ethiopiaextractivesminingstrategicassessmentmineralsector (dostęp: 23.12.2019).
} 
specjalne instytucje mające na celu finansowanie tych przedsięwzięć. Trzeba zaznaczyć, że wiele projektów zostało dotowanych przez EXIM Bank of China, utworzony przed ogłoszeniem planów dotyczących realizacji koncepcji „Jeden pas, jedna droga" ${ }^{29}$. Znając model chiński, można przypuszczać, że wszystkie pożyczki pochodzące $z$ instytucji finansowych lub banków komercyjnych są realizowane za zgodą władz w Pekinie.

Projekty inwestycyjne w obszarze transportu, które cieszą się największym zainteresowaniem badaczy, realizowane są w Kenii oraz Dżibuti. Chiński bank razem z rządem kenijskim finansuje modernizację portu w Mombasie oraz budowę portu w Lamu. Kapitał pochodzący z Chin dotuje też rozwój linii kolejowej i gazociągu, który ma połączyć w przyszłości porty w Kenii z polami ropy naftowej w Ugandzie i Sudanie Południowym ${ }^{30}$. Inwestycje te są strategiczne dla Chin oraz państw regionu, ponieważ umożliwiają bezpieczny transport dóbr mających największe znaczenie dla rozwoju gospodarczego tych państw. Gazociąg odgrywa szczególnie ważną rolę w polityce gospodarczej Sudanu Południowego, ponieważ dzięki niemu państwo to może się uniezależnić od infrastruktury należącej do Sudanu ${ }^{31}$. Istotnym ogniwem w tranzycie lądowym jest transport kolejowy, uważany za jeden z najlepszych sposobów przemieszczania dóbr. Dlatego projekt dotyczący połączenia Kenii z Ugandą ma tak duże znaczenie dla takich krajów, jak Rwanda i Burundi, które dzięki realizacji inwestycji uzyskają możliwość sprawnego połączenia z portem w Mombasie ${ }^{32}$.

Dżibuti to państwo znajdujące się na wschodnim wybrzeżu Afryki, które ma kluczowe znaczenie dla transportu międzynarodowego ${ }^{33}$. Jego położenie w pobliżu Morza Czerwonego, Zatoki Adeńskiej oraz Kanału Sueskiego, przez wody którego przepływa $8 \%$ światowego handlu ${ }^{34}$, implikuje duże zainteresowanie głównych aktorów ładu międzynarodowego. Chińskie podmioty finansowe dotowały w tym kraju budowę linii kolejowej, która połączyła port w Dżibuti ze stolicą Etiopii - Addis Abebą. Przez port ten przechodzą towary, które stanowią 95\% etiopskiego eksportu ${ }^{35}$. Chińskie zaangażowanie nie ogranicza się tu jedynie do finansowania projektów inwestycyjnych. Przedsiębiorstwo ma-

\footnotetext{
${ }^{29} \mathrm{http}: / /$ www.sais-cari.org/ (dostęp: 23.12.2019).

${ }^{30} \mathrm{R}$. ZiroMwatela, Z. Changfeng, op. cit.

${ }^{31} \mathrm{D}$. Scopas, Bound by oil: How petroleum is bringing Sudan and South Sudan closer together, https://www.middleeasteye.net/news/boundoilhowpetroleumbringingsudanandsouthsudanclosertogether (dostęp: 23.12.2019).

${ }^{32} \mathrm{R}$. ZiroMwatela, Z. Changfeng, op. cit.

${ }^{33}$ World powers look to Djibouti for trade, military access, https://www.youtube.com/ watch?v=k6XjFPI3QAA (dostęp: 27.12.2019).

${ }^{34}$ Suez Canal: China's Trade Flows via the Suez, https://www.business.hsbc.ae/engb/ae/article/ suezcanalchinastradeflowsviathesuez (dostęp: 27.12.2019).

${ }^{35} \mathrm{H}$. Wismayer, A Remarkable Rail Fourney Into the Horn of Africa's Past, and Future, https:// www.nytimes.com/2019/04/08/travel/ethiopiatrainhararaddisababa.html (dostęp: 27.12.2019).
} 
jące kapitał pochodzący z Chin posiada pakiet akcji terminalu kontenerowego, który został w kontrowersyjnych okolicznościach odebrany dotychczasowym właścicielom $^{36}$. Firma chińska odpowiada też za stworzenie strefy handlowej, na terenie której pracę znajdzie 20 tysięcy osób ${ }^{37}$. Liczba oraz znaczenie tych inwestycji pokazuje, jak ważnym miejscem dla chińskich interesów jest to niewielkie państwo, które również potrafi skutecznie czerpać korzyści ze swojego strategicznego położenia. W 2017 roku Chińska Republika Ludowa otworzyła swoją pierwszą zagraniczną bazę wojskową właśnie na terenie tego państwa. Dołączyła ona tym samym do grona takich graczy międzynarodowych, jak Stany Zjednoczone, Włochy, Japonia oraz Francja, które również posiadają tego typu obiekty w Dżibuti ${ }^{38}$. Kraj ten za dzierżawę terenów rocznie otrzymuje około 150 mln dolarów, co w znaczący sposób zwiększa jego budżet ${ }^{39}$. Chiny w dużej mierze koncentrują się na budowie infrastruktury, która ma zapewnić korzyści światowemu handlu oraz rozszerzyć ich wpływy na świecie, jednak realizują również projekty humanitarne. Przykładem tego typu działań jest budowa wodociągu pomiędzy Etiopią i Dżibuti, dostarczającego wodę pitną dla 700 tysięcy mieszkańców Dżibuti ${ }^{40}$.

\section{Konsekwencje obecności chińskich inwestycji w Afryce}

Wraz ze zwiększającym się zaangażowaniem chińskiego kapitału w krajach afrykańskich pojawiło się wiele komentarzy, które zwracały uwagę na implikacje ekonomiczne tej obecności. Głównym zarzutem kierowanym w stronę Chińskiej Republiki Ludowej jest prowadzenie polityki debt diplomacy (dyplomacja długu - M.K.). Mechanizm ten polega na oferowaniu kredytów państwom rozwijającym się w takich ilościach, aby nie mogły one ich spłacić. W konsekwencji pożyczkobiorca staje się podmiotem zależnym od woli pożyczkodawcy. Jeżeli taka sytuacja wystąpiłaby w krajach Afryki, to chińskie podmioty mogłyby przejąć kontrolę nad strategiczną infrastrukturą transportową oraz energetyczną ${ }^{41}$. Argumenty powyższe są używane nie tylko

\footnotetext{
${ }^{36}$ M.A. Kuo, China in Djibouti: The Power of Ports, https://thediplomat.com/2019/03/chinaindjiboutithepowerofports/ (dostęp: 28.12.2019).

${ }^{37}$ China's Belt and Road initiative and its implications for Africa - WWF, Nairobi 2016, s. 22, http://assets.wwfke.panda.org/downloads/china_s_belt_and_road_initiative_and_its_implications_for_africa.pdf (dostęp: 27.12.2019).

${ }^{38}$ L. Blanchard, S.R. Collins, China's Engagement in Djibouti, https://fas.org/sgp/crs/row/ IF11304.pdf (dostęp: 27.12.2019).

${ }^{39}$ World powers look to Djibouti for trade...

${ }^{40}$ Ethiopia-Djibouti Water Project to be inaugurated soon, https://www.africanreview.com/ manufacturing/water-a-environment/ethiopia-djibouti-water-project-to-be-inaugurated-soon (dostęp: 29.12.2019).

${ }^{41}$ M. Green, China's Debt Diplomacy, https://foreignpolicy.com/2019/04/25/chinasdebtdiplomacy/ (dostęp: 29.12.2019).
} 
przez analityków lub badaczy, lecz również przez polityków międzynarodowych. Jako przykład można tu podać przemówienie wiceprezydenta Stanów Zjednoczonych z października 2018 roku, w którym wprost zarzucił Chinom stosowanie mechanizmu debt diplomacy ${ }^{42}$.

Głównym przykładem przedstawianym przez krytyków Chińskiej Republiki Ludowej jest sytuacja Sri Lanki, która z powodu zadłużenia zdecydowała się na oddanie $70 \%$ udziałów oraz przekazanie w dzierżawę na 99 lat nowo wybudowanego portu w Hambantota. Jednak po dokładniejszej analizie tego przypadku można dojść do wniosku, że dług zaciągnięty u chińskich podmiotów nie jest głównym powodem problemów tego azjatyckiego kraju ${ }^{43}$. Państwem afrykańskim, o którym najwięcej pisze się w kontekście debt diplomacy, jest Dżibuti - zobowiązania względem chińskich podmiotów stanowią $80 \%$ długu zagranicznego ${ }^{44}$. Znając strategiczne położenie tego kraju, sytuacja ta musi budzić zaniepokojenie graczy międzynarodowych. Jednak przyglądając się bliżej opisywanemu zjawisku, można stwierdzić, że argumenty związane z celowym stosowaniem dyplomacji długu są przesadzone. Badacze wskazują, że $20 \%$ całego długu zagranicznego kontynentu afrykańskiego należy do Chin, natomiast $35 \%$ do organizacji multilateralnych (np. Banku Światowego) ${ }^{45}$. Natomiast port w Hambantota jest jedynym przypadkiem na ponad 3000 projektów, w którym przekazano infrastrukturę transportową chińskim wierzycielom ${ }^{46}$. Państwom afrykańskim udawało się również renegocjować umowy kredytowe. Przykładem jest tu Demokratyczna Republika Kongo, która wydłużyła czas zwrotu pożyczonych pieniędzy o 15 lat, zaś Etiopii umorzono część kredytów zaciągniętych na budowę linii kolejowej ${ }^{47}$. Ogółem w latach 2000-2017 odnotowano powyżej 80 przypadków, w których to chińskie podmioty renegocjowały warunki spłaty zadłużenia ${ }^{48}$. Przywołane przykłady pokazują, że głównym celem Chińskiej Republiki Ludowej nie jest przejmowanie krytycznej infrastruktury państw rozwijających się za pomocą stosowania mechanizmu debt diplomacy. Tego typu działania mogłyby mieć duże konsekwencje ekonomiczne oraz polityczne dla Chin. Temu państwu w trwającej obecnie wojnie handlowej

${ }^{42}$ Remarks by Vice President Pence on the Administration's Policy Toward China, https://www. whitehouse.gov/briefingsstatements/remarksvicepresidentpenceadministrationspolicytowardchina/ (dostęp: 29.12.2019).

${ }^{43}$ U. Moramudali, Is Sri Lanka Really a Victim of China's „Debt Trap”?, https://thediplomat. com/2019/05/is-sri-lanka-really-a-victim-of-chinas-debt-trap/ (dostęp: 29.12.2019).

${ }^{44}$ The risk of relying on Chinese cash, „The Economist”, 21.07.2018, s. 26.

${ }^{45}$ Choices on the continent, „The Economist”, 9.03.2019, s. 18-20.

${ }^{46}$ Seeds of suspicion, „The Economist”, 27.04.2019, s. 47-48.

${ }^{47} \mathrm{~J}$. Nyabiage, Are Chinese infrastructure loans putting Africa on the debt trap express?, https:// www.scmp.com/news/china/diplomacy/article/3020394/arechineseinfrastructureloansputtingafricadebttrap (dostęp: 29.12.2019).

${ }^{48}$ Seeds of suspicion... 
ze Stanami Zjednoczonymi potrzebni są sojusznicy. Stosowanie dyplomacji długu mogłoby natomiast przynieść skutek odstraszający.

Rzeczywistym problemem, z którym zmagają się państwa afrykańskie oraz Chiny, jest fakt nieopłacalności niektórych projektów inwestycyjnych. Przykładem godnym odnotowania jest linia kolejowa łącząca Etiopię z Dżibuti. $\mathrm{Z}$ powodu małej liczby pasażerów korzystających z tego rodzaju transportu chiński ubezpieczyciel stracił już miliard dolarów ${ }^{49}$. W Kenii, która zmaga się z korupcją, opłata za przewóz dóbr transportem kolejowym jest dwa razy wyższa od średniej światowej, co jest ceną zaporową dla wielu przedsiębiorców działających na tamtejszym rynku. W trakcie budowy linii kolejowej popełniono również błędy obliczeniowe związane z przepustowością, w wyniku czego działa ona w mniejszym stopniu, niż planowano ${ }^{50}$. Choć cechą projektów dotyczących infrastruktury lądowej jest fakt długiego okresu zwrotu inwestycji, to kraje afrykańskie oraz chińskie podmioty z większą uwagą oraz roztropnością powinny podchodzić do fazy planowania inwestycji. Bez dróg dojazdowych do portów lub stacji przeładunkowych nie uda się stworzyć odpowiednich warunków do sprawnej wymiany handlowej.

Konsekwencją wspomnianych wyżej błędów jest wycofywanie się niektórych państw afrykańskich z projektów inwestycyjnych. Sierra Leone z powodu wątpliwości co do opłacalności budowy lotniska zdecydowało, że nie zgodzi się na jego budowę, która miała być finansowana przez chiński bank. Takie samo stanowisko przyjęła Tanzania w związku z budową portu w Bagamoyo. W jej przypadku nie zgodzono się na zaporowe warunki najmu tej infrastruktury przez chiński podmiot ${ }^{51}$. Decyzje owe uderzyły bezpośrednio we flagowy projekt prezydentury Xi Jinpinga, w rezultacie Chiny zostały zmuszone do zmiany podejścia do projektów infrastrukturalnych. W kwietniu 2019 roku prezydent Chińskiej Republiki Ludowej zapowiedział, że od tej pory przy zawieraniu umów będzie się przywiązywało większą wagę do transparentności procesu oraz możliwości kredytowych pożyczkobiorcy ${ }^{52}$. Słowa te są implikacją wcześniejszych decyzji, ponieważ już w 2017 roku Chiny zmniejszyły kwotę pożyczek dla krajów afrykańskich do poziomu około 11 mld dolarów - w 2016 roku łączna suma kredytów przekraczała 30 mld dolarów ${ }^{53}$. Redukcja ta mogła mieć związek z przewidywaniami chińskich władz co do rozpoczęcia wojny handlowej przez Stany Zjednoczone. Zapowiedzi Chin, związane z zapewnieniem

\footnotetext{
${ }^{49}$ Choices on the continent...

${ }^{50}$ Beijing curbs its...

${ }^{51}$ L. Hartman, Countries in Africa Reject Belt and Road Deals, https://share.america.gov/countriesinafricarejectbeltandroaddeals/ (dostęp: 29.12.2019).

${ }^{52}$ C.H. Wong, J.T. Areddy, China's Xi Vows New Direction for „Belt and Road” after Criticism, https://www.wsj.com/articles/chinas-xi-vows-new-direction-for-belt-and-road-after-criticism-11556249652 (dostęp: 29.12.2019).

${ }^{53}$ Beijing curbs its...
} 
większej transparentności w trakcie procesów kredytowych, można uznać za ruch w dobrą stronę. Będą one mieć wpływ na stopień uczestnictwa w projektach inwestycyjnych partnerów zagranicznych.

Chińskie inwestycje mają również duży wpływ na codzienne życie mieszkańców państw afrykańskich. Wraz z napływem kapitału rośnie zapotrzebowanie na pracowników, przez co zwiększa się liczba zatrudnionych ${ }^{54}$. Praca jest głównym czynnikiem wzrostu poziomu dobrobytu i to na tym fundamencie powinno się budować przyszłość społeczeństwa. Chińskie przedsiębiorstwa działające w branży budowlanej, które obecne są w Ghanie, oferują swoim pracownikom kursy mające ich przygotować do wypełniania swoich zawodowych obowiązków. Oprócz szkoleń dotyczących bezpieczeństwa, pracownicy mają możliwość wzięcia udziału w specjalnie dla nich przygotowanych programach, których celem jest rozwinięcie ich umiejętności potrzebnych do pracy w sektorze budowlanym ${ }^{55}$. Podobne praktyki stosowane są też w firmach tekstylnych, które mają swoje siedziby w specjalnej strefie ekonomicznej w Etiopii. Osoby tam zatrudnione są przygotowywane do szycia ubrań eksportowanych następnie do Europy ${ }^{56}$. Działania podejmowane przez chińskie przedsiębiorstwa przyczyniają się do budowania kapitału społecznego w państwach afrykańskich. Osoby uczestniczące w szkoleniach zwiększają swoją pozycję na lokalnym rynku pracy. W wielu przypadkach nie mają potem problemów ze znalezieniem zatrudnienia w lepiej płatnych gałęziach gospodarki ${ }^{57}$.

Zgodnie z zasadami zrównoważonego rozwoju coraz więcej chińskich firm angażuje się w projekty społeczne. Przedsiębiorstwa te biorą udział w budowie budynków użyteczności publicznej ${ }^{58}$ oraz dotują programy rekompensacyjne dla mieszkańców, którzy musieli zmienić miejsce zamieszkania ${ }^{59} \mathrm{z}$ powodu re-

${ }^{54}$ D. Fei, Work, Employment, and Training through Africa-China Cooperation Zones: Evidence from the Eastern Industrial Zone in Ethiopia, s. 15, https://static1.squarespace.com/static/5652847de4b033f56d2bdc29/t/5b9a9dcd575d1f3c474af67f/1536859598690/Ding+Fei+_+Working+Paper+_+V2.pdf (dostęp: 4.03.2020).

${ }^{55}$ M. Qingwei, E. Nyantakyi, Local Skill Development from China's Engagement in Africa: Comparative Evidence from the Construction Sector in Ghana, s. 8, https://static1.squarespace. com/static/5652847de4b033f56d2bdc29/t/5cdc2a3be79c70bc2cb9f1d0/1557932603882/WP22MengandNyantakyiLocalSkillDevelopment.pdf (dostęp: 4.03.2020).

${ }^{56}$ D. Fei, op. cit., s. 20.

${ }^{57}$ M. Qingwei, E. Nyantakyi, op. cit., s. 22.

${ }^{58}$ W. Cheng, G. Liang, Social responsibility of Chinese investment in Africa: What does it mean for EU-China Cooperation on development policy towards Africa?, https://www.ictsd.org/ bridgesnews/tradenegotiationsinsights/news/socialresponsibilityofchineseinvestmentinafrica (dostęp: 4.04.2020).

${ }^{59}$ T. Keyi, Y. Shen, Do China Financed Dams in Sub-Saharan Africa Improve the Region's Social Welfare? A Case Study of the Impacts of Ghana's Bui Dam, s. 13, https://static1.squarespace. com/static/5652847de4b033f56d2bdc29/t/5cdc2a755fbd1300012a2aa0/1557932662293/ WP201904TangShenBuiDam.pdf (dostęp: 4.04.2020). 
alizacji inwestycji infrastrukturalnych. Znany jest również przypadek, gdy to firma chińska z branży budowlanej realizuje szkolenia dla nauczycieli szkół zawodowych, aby mogli oni odpowiednio przygotować młodzież do wejścia na rynek pracy ${ }^{60}$. Powyższe przykłady potwierdzają, że duże przedsiębiorstwa z Chin zaczynają czerpać wzorce z zachodnich firm, które również zwracają uwagę na zagadnienia związane ze wsparciem społeczności lokalnych.

Działalność chińskich firm w Afryce ma również negatywne oblicze. W wielu przedsiębiorstwach droga awansu dla lokalnych pracowników jest ograniczona. Nawet po odbyciu kursów i dłuższym stażu pracy nie są oni angażowani w podejmowanie decyzji związanych ze strategiczną działalnością firm ${ }^{61}$. Menadżerowie z Chin nie zawsze są odpowiednio przygotowani do rozwiązywania konfliktów z pracownikami. Brak zrozumienia dla pewnych różnic kulturowych może doprowadzić do tragedii. Przykładem jest strajk osób zatrudnionych w zambijskiej kopalni, w wyniku którego życie stracili górnicy ${ }^{62}$. Łamanie praw pracowniczych to również spory problem przedsiębiorstw działających w Afryce. W chińskich firmach dochodziło do przypadków zwolnień z powodu chęci stworzenia związków zawodowych w zakładach pracy ${ }^{63}$. Wiele osób zatrudnionych w tych przedsiębiorstwach nie zawsze posiada stosowną umowę o pracę, przez co nie mają zagwarantowanego podstawowego pakietu socjalnego ${ }^{64}$. Tego typu sytuacje występują nie tylko w firmach z chińskim kapitałem. To praktyka powszechna w przedsiębiorstwach, które obecnie funkcjonują na całym świecie.

\section{Konkluzje}

Chińska Republika Ludowa i państwa Afryki posiadają długą historię wspólnej kooperacji. Choć po II wojnie światowej współpraca ta była motywowana głównie kwestiami ideologicznymi, to w ostatnich latach ma ona podłoże czysto ekonomiczne, związane z szybko rozwijającym się rynkiem kontynentu afrykańskiego. Kraje Afryki zajmują też ważne miejsce w strategii ChRL. Koncepcja OBOR ma na celu poprawę pozycji Chin w systemie gospodarczym, jednak może mieć również pozytywny wpływ na rozwój ekonomiczny państw Afryki. Decyzje podjęte w ramach współpracy pomiędzy ChRL i kontynentem

${ }^{60}$ S.I. Yuan, L. Qi, Creating a market for skills transfer: A case study of a AVIC International's skills transfer programs in Kenya, s. 16, https://static1.squarespace.com/static/5652847de4b033f56d2bdc29/t/59c16bdd32601e607092429a/1505848312981/irene+v2.pdf (dostęp: 4.04.2020).

${ }^{61}$ D. Fei, op. cit., s. 19.

${ }^{62}$ China's rising influence in Africa: Is there room for CSR?, s. 4, https://www.bsr.org/reports/ BSR_China_Rising_Influence_in_Africa.pdf (dostęp: 4.04.2020).

${ }^{63} \mathrm{R}$. Zander, H. Huang, We are not so different: A comparative study of employment relations at Chinese and American firms in Kenya, s. 11, https://static1.squarespace.com/static/5652847de4b033f56d2bdc29/t/58da9416e4fcb5845eb6da4a/1490719767135/zander+v1.pdf (dostęp: 4.04.2020).

${ }^{64}$ Ibidem. 
afrykańskim skutkują zwiększeniem wartości wymiany handlowej pomiędzy tymi podmiotami, a także wzrostem wzajemnych współzależności.

Kapitał chiński jest inwestowany głównie w projekty modernizujące szlaki transportowe, co jest zgodne z kierunkiem wytyczonym przez prezydenta Chińskiej Republiki Ludowej Xi Jinpinga. Bez realizacji tych koncepcji Chinom nie uda się uzyskać większej kontroli nad głównymi drogami tranzytowymi. Głównymi beneficjentami tych planów będą jednak państwa Afryki, które w większym stopniu zostaną zintegrowane z międzynarodowym systemem handlowym.

Wraz ze zwiększającym się zaangażowaniem chińskich firm w regionie afrykańskim zaczęły pojawiać się komentarze mające na celu zdyskredytowanie metod działań przedstawicieli z Chin. Głównym argumentem wysuwanym przez krytyków jest stosowanie polityki debt diplomacy, która ma prowadzić do odbierania afrykańskim partnerom strategicznych elementów infrastruktury transportowej. Kroki podejmowane przez chińskie podmioty nie wskazują jednak na celowe stosowanie dyplomacji długu, a oskarżenia te mają przede wszystkim zniechęcić potencjalnych partnerów do współpracy z Chinami. Sytuację należy uważnie monitorować, ponieważ strata płynności finansowej przez państwa afrykańskie może mieć poważne konsekwencje dla sytuacji gospodarczej państw regionu.

Chińskie przedsiębiorstwa inwestując w Afryce, zmieniają codzienne życie jej mieszkańców. Dzięki ich finansowemu zaangażowaniu ludzie mają możliwość znalezienia pracy, co podnosi poziom ich życia. Firmy te angażują się również w projekty mające na celu budowę kapitału społecznego w państwach afrykańskich, przez co poprawia się sytuacja lokalnych mieszkańców na rynku pracy. Programy skierowane na rozwój kompetencji zawodowych oraz podniesienie poziomu edukacji to jedyna droga do wzrostu gospodarczego państw. W przeszłości to właśnie podobna strategia zapewniła Chinom dzisiejszą pozycję na arenie międzynarodowej. Kluczową kwestią wydaje się zwrócenie większej uwagi na różnice kulturowe oraz prawne dzielące ChRL i kraje afrykańskie. Zastosowanie odpowiednich narzędzi związanych z ochroną praw pracowniczych może przynieść pozytywne efekty dla wzrostu gospodarczego Afryki.

\section{Bibliografia}

Beijing curbs its enthusiasm, „The Economist”, 29.06.2019.

Blanchard L., Collins R.S., China's Engagement in Djibouti, https://fas.org/sgp/crs/row/ IF11304.pdf (dostęp: 27.12.2019).

Can Ethiopia's Resource Wealth Contribute to its Growth and Transformation?, https:// www.worldbank.org/en/news/feature/2015/01/26/ethiopia-extractives-miningstrategic-assessment-mineral-sector (dostęp: 23.12.2019). 
Cheng W., Liang G., Social responsibility of Chinese investment in Africa: What does it mean for EU-China Cooperation on development policy towards Africa?, https://www. ictsd.org/bridges-news/trade-negotiations-insights/news/social-responsibility-ofchinese-investment-in-africa (dostęp: 4.04.2020).

China has a serious crisis on its hands, https://www.youtube.com/watch?v=Zpzhh0y1RUo (dostęp: 21.12.2019).

China's Belt and Road initiative and its implications for Africa - WWF, Nairobi 2016, http://assets.wwfke.panda.org/downloads/china_s_belt_and_road_initiative_and_ its_implications_for_africa.pdf (dostęp: 27.12.2019).

China's rising influence in Africa: Is there room for CSR?, https://www.bsr.org/reports/B SR_China_Rising_Influence_in_Africa.pdf (dostęp: 21.12.2019).

Choices on the continent, „The Economist”, 9.03.2019.

Cookson C., Africa to propel world's population towards 10 bn by 2050, https://www. ft.com/content/868e20d0-90ec-11e9-b7ea-60e35ef678d2 (dostęp: 21.12.2019).

Ethiopia-Djibouti Water Project to be inaugurated soon, https://www.africanreview. $\mathrm{com} /$ manufacturing/water-a-environment/ethiopia-djibouti-water-project-to-beinaugurated-soon (dostęp: 29.12.2019).

Fei D., Work, Employment, and Training through Africa-China Cooperation Zones: Evidence from the Eastern Industrial Zone in Ethiopia, https://static1.squarespace.com/ static/5652847de4b033f56d2bdc29/t/5b9a9dcd575d1f3c474af67f/1536859598690/ Ding+Fei+_+Working+Paper+_+V2.pdf (dostęp: 4.03.2020).

Gawęda W., Lehman Brothers - symboliczny upadek, który rozpocząt kryzys finansowy, https://www.forbes.pl/gospodarka/upadek-lehman-brothers-rozpoczal-kryzysfinansowy-w-2008-roku/7j1fgjh (dostęp: 21.12.2020).

Góralczyk B., Chiny piątej generacji, https://www.obserwatorfinansowy.pl/tematyka/ makroekonomia/chiny-piatej-generacji/ (dostęp: 20.12.2020).

Green M., China's Debt Diplomacy, https://foreignpolicy.com/2019/04/25/chinas-debtdiplomacy/ (dostęp: 29.12.2019).

Hartman L., Countries in Africa Reject Belt and Road Deals, https://share.america.gov/ countries-in-africa-reject-belt-and-road-deals/ (dostęp: 29.12.2019).

Holslag J., China's New Mercantilism in Central Africa, „African and Asian Studies” 2006, Vol. V, No. 2.

Jinping X., Innowacyjne Chiny, Warszawa 2015.

Keyi T., Shen Y., Do China-Financed Dams in Sub-Saharan Africa Improve the Region's Social Welfare? A Case Study of the Impacts of Ghana's Bui Dam, https://static1. squarespace.com/static/5652847de4b033f56d2bdc29/t/5cdc2a755fbd1300012a2 aa0/1557932662293/WP-2019-04-Tang-Shen-Bui-Dam.pdf (dostęp: 4.04.2020).

Kissinger H., O Chinach, Wołowiec 2014.

Kuo M.A., China in Djibouti: The Power of Ports, https://thediplomat.com/2019/03/chinain-djibouti-the-power-of-ports/ (dostęp: 28.12.2019).

Lammers E., How will the Beijing Consensus benefit Africa? - China and Africa, https:// www.thebrokeronline.eu/how-will-the-beijing-consensus-benefit-africa/ (dostęp: 21.12.2020). 
Monson J., Africa's Freedom Railway: How a Chinese Development Project Changed Lives and Livelihoods in Tanzania, Bloomington 2009.

Moramudali U., Is Sri Lanka Really a Victim of China's „Debt Trap”?, https://thediplomat. com/2019/05/is-sri-lanka-really-a-victim-of-chinas-debt-trap/ (dostęp: 29.12.2019).

More than minerals, „The Economist”, 23.03.2013.

Nantulya P., Implications for Africa from China's One Belt One Road Strategy, https:// africacenter.org/spotlight/implicationsforafricachinaonebeltoneroadstrategy/ (dostęp: 21.12.2020).

The new scramble for Africa, „The Economist”, 9.03.2019.

Nowak W., China-Africa and India-Africa trade in the years 2000-2014, „Procedia Economics and Finance" 2016, Vol. XXXIX.

Nowak W., China's Development Aid Strategies, „Chinese Business Review” 2015, Vol. XIV, No. 4.

Nyabiage J., Are Chinese infrastructure loans putting Africa on the debt-trap express?, https://www.scmp.com/news/china/diplomacy/article/3020394/are-chineseinfrastructureloans-puttingafrica-debt-trap (dostęp: 29.12.2019).

Obuah E., Trade between China and Africa: Trends, Changes, and Challenges, „International Journal of China Marketing” 2012, Vol. II, No. 2.

One among many, „The Economist”, 17.01.2015.

Premier Zhou Enlai's Three Tours of Asian and African Countries, https://www.fmprc.gov.cn/ mfa_eng/ziliao_665539/3602_665543/3604_665547/t18001.shtml (dostęp: 20.12.2020).

Qingwei M., Nyantakyi E., Local Skill Development from China's Engagement in Africa: Comparative Evidence from the Construction Sector in Ghana, https://static1. squarespace.com/static/5652847de4b033f56d2bdc29/t/5cdc2a3be79c70bc2cb9f 1d0/1557932603882/WP-22-Meng-and-Nyantakyi-Local-Skill-Development.pdf (dostęp: 4.03.2020).

Remarks by Vice President Pence on the Administration's Policy Toward China, https:// www.whitehouse.gov/briefings-statements/remarks-vice-president-penceadministrations-policy-toward-china/ (dostęp: 29.12.2019).

Rich in resources but poor and corrupt, https://www.dw.com/en/rich-in-resources-butpoor-and-corrupt/av-40200307 (dostęp: 23.12.2019).

The risk of relying on Chinese cash, „The Economist”, 21.07.2018.

Scopas D., Bound by oil: How petroleum is bringing Sudan and South Sudan closer together, https://www.middleeasteye.net/news/bound-oil-how-petroleum-bringing-sudanand-south-sudan-closer-together (dostęp: 23.12.2019).

Seeds of suspicion, „The Economist”, 27.04.2019.

Suez Canal: China's Trade Flows Via The Suez, https://www.business.hsbc.ae/en-gb/ae/ article/suez-canal-chinas-trade-flows-via-the-suez (dostęp: 27.12.2019).

Wismayer H., A Remarkable Rail fourney Into the Horn of Africa's Past, and Future, https:/www.nytimes.com/2019/04/08/travel/ethiopia-train-harar-addis-ababa.html (dostęp: 27.12.2019).

Wong U., Areddy J.T., China's Xi Vows New Direction for „Belt and Road” after Criticism, https://www.wsj.com/articles/chinas-xi-vows-new-direction-for-belt-and-roadafter-criticism-11556249652 (dostęp: 29.12.2019). 
World powers look to Djibouti for trade, military access, https://www.youtube.com/ watch?v=k6XjFPI3QAA (dostęp: 27.12.2019).

Yuan I.S., Qi L., Creating a market for skills transfer: A case study of a AVIC International's skills transfer programs in Kenya, https://static1.squarespace.com/ static/5652847de4b033f56d2bdc29/t/59c16bdd32601e607092429a/1505848312981/ irene+v2.pdf (dostęp: 4.04.2020).

Zander R., Huang H., We are not so different: A comparative study of employment relations at Chinese and American firms in Kenya, https://static1.squarespace.com/ static/5652847de4b033f56d2bdc29/t/58da9416e4fcb5845eb6da4a/1490719767135/ zander+v1.pdf (dostęp: 4.04.2020).

ZiroMwatela R., Changfeng Z., Africa in China's „One Belt, One Road” Initiative: A Critical Analysis, „IOSR Journal of Humanities And Social Science” 2016, Vol. XXI, No. 12 , s. $10-21$.

http://www.sais-cari.org/data (dostęp: 23.12.2019).

http://www.sais-cari.org/data-china-africa-trade (dostęp: 21.12.2019).

https://wits.worldbank.org/CountryProfile/en/Country/CHN/Year/2017/TradeFlow/ Export/Partner/SSF/Product/all-groups (dostęp: 21.12.2019). 